\title{
HISTÓRIA DO ANTISSEMITISMO
}

\section{Ana Carolina Alves da Silva ${ }^{1}$ Valéria Regina Zanetti ${ }^{2}$}

Resumo: o presente artigo apresenta um debate historiográfico acerca do antissemitismo, termo que designa manifestações de hostilidade contra judeus, tendo como enfoque dois momentos ímpares na historia europeia: a Inquisição Espanhola, instaurada em 1478 pelo papa Xisto IV a pedido da rainha Isabel de Castela; e o Holocausto, genocídio em massa que custou a vida de milhões de judeus no século XX. Busca-se apontar os fatores que podem ter causado ou corroborado na construção dessa ideologia em cada um desses episódios, para então averiguar se há compatibilidade nos motivos que fundamentaram uma política de perseguição, terror e extermínio dos judeus.

Palavras-chave: Antissemitismo; Judeus; Economia; Nacionalismo; História.

1 Faculdade de Educação de Artes/Universidade do Vale do Paraíba/Univap, Brasil. E-mail: carolinaana967@gmail.com.

2 Faculdade de Educação de Artes/Universidade do Vale do Paraíba/Univap, Brasil. E-mail: vzanetti@univap.br. 